\title{
Nutrient status of scavengable feed resources in crop and gizzard contents of three genotypes of ducklings
}

\author{
MM Rahman', MJ Khan*2, MA Akbar² \\ ${ }^{1}$ Department of Livestock Services, Rajshahi; ${ }^{2}$ Department of Animal Nutrition, Bangladesh Agricultural \\ University, Mymensingh 2202, Bangladesh
}

\begin{abstract}
An investigation was carried out with 54 scavenging ducklings of three genotypes belonging to three age groups ( 6,10 and 14 weeks) taking from 3 areas reared under two feeding regimes. The birds were sacrificed from farmer's house between 4.0 and 5.0 P.M. They were dissected to identify crop and gizzard contents (CGC). Cereal grains, bran, green forages, insects and worms were the main CGC and their composition varied significantly $(p<0.01)$ with genotypes and feed. CGC were collected for chemical analysis. The CGC was processed and analyzed for proximate components, calcium (Ca) and total phosphorus (TP). It contained $88.06 \%$ DM, 10.15\% CP, $13.65 \%$ CF, 2.89\% EE, 15.51\% Ash, 57.80\% NFE, $1.42 \% \mathrm{Ca}, 0.40 \% \mathrm{TP}$ and $2264 \mathrm{kcal} / \mathrm{kg}$ DM TME. Genotypes and feed had significant effect $(p<0.01)$ on CP, CF, EE, Ash, Ca and TP at 6 weeks of age but genotypes and feed showed no significant variations $(p>0.05)$ on TME for the same period. It may be concluded that the scavenging feeds are deficient in CP, Ca and TP but excess in crude fibre. So, the concentration of the nutrients (except CF and ash) available to the scavenging ducklings under rural condition may be treated as below the suggested nutrient requirements for ducklings.
\end{abstract}

Key words: Chemical composition, duckling, feed supplementation, coastal areas

Bangladesh Animal Husbandry Association. All rights reserved. Bang. J. Anim. Sci. 2014.43 (3): 185-191

\section{Introduction}

Ducklings in Bangladesh are generally scavengers, foraging in the water bodies fed on snails, a variety of small fishes, crabs, duck weeds, algae, plant materials, various types of insects, tadpoles, oysters, earthworms and also varieties of crop wastes especially rice polish. Scavenging feed resources (SFR) comprising materials from the surrounding environment, byproducts from harvesting and processing grains and cultivated and wild vegetation, are frequently utilized by ducklings (Tadelle et al. 2002). It is revealed from the study that the materials present in the crop and gizzard, as visually observed, were seeds, plant materials, worms, insects and unidentified materials (Tadelle and Ogle 2000). Before proposing any comprehensive program for the improvement of feeding of a duck production unit, it is essential to know the existing status of nutrients obtained by the scavenging ducklings. The task of improving the nutritional status of scavenging ducklings is difficult because the quantity and quality of the scavenged feed is not known definitely (Roberts and Gunaratne 1992). Previous efforts to determine nutritional status of scavenging birds were mostly directed for chicken (Mwalusanya et al. 2002) and therefore, there is a lack of information on the availability and nutritional status of scavenging ducklings except that of Biswas et al. (2005). The information on the scavengable feed resources for ducklings, their availability and nutrient composition in the southern district of Bangladesh is very limited. So, the present experiment was undertaken to collect information about the availability of feed resources of ducklings and to determine the physical and chemical composition of feeds available in crop and gizzard of ducklings reared under scavenging condition in Noakhali district of Bangladesh.

\section{Materials and Methods}

The experiment was conducted at three villages of Noakhali district in Bangladesh for a period of 98 days. Day-old ducklings of three genotypes viz. Muscovy, Pekin and Desi white were collected from Central Duck Breeding Farm, Narayangonj 


\section{Crop and gizzard contents of ducklings}

and assigned at random in a 2 (feeding regimes) $\times 3$ (genotypes) factorial experiment in a Randomized Block Design having 3 replicates in each treatment. The birds of control group received feed only from scavenging and the birds of supplementary group received mash feed in addition to normal scavenging. The experimental birds were allowed to scavenged freely in the agricultural fields, ponds and ditches nearer to farmer's house from 8.00 to 16.00 hours daily. In addition to scavenging feed, the birds belonging to supplementary group received a concentrate mixture composed of $50 \%$ rice polish, $30 \%$ broken rice and $20 \%$ wheat bran in the from of wet mash. Supplementary feeds were given @ $10 \mathrm{~g}$ in the first week which was further increased @ $10 \mathrm{~g}$ in each week until 8 weeks. The supplemental feeds were divided into two equal portions and were given twice daily. The present investigation involved the identification of physical composition of crop and gizzard contents (CGC) and the determination of chemical composition of CGC of scavengable ducklings in coastal areas of Bangladesh.

Sampling was done three times during the experimental period. The first time at 6 weeks of age, the second time at 10 weeks of age and the third time at 14 weeks of age. Ducklings were slaughtered at 6,10 and 14 weeks of age to study the physical and chemical composition of CGC of scavengable ducklings. At each time, 3 birds from each genotype were randomly slaughtered at 2, 4 and 6 hours of scavenging following 'halal' method by severing the jugular vein and allowed to bleed completely Singh et al. (2003).

A total of 54 ducklings were randomly collected from different villages of the study area for collecting CGC. The number of ducklings and their plan for slaughtering are summarized in Table 1. The ducklings were confined in farmers house between 4.0 and 5.0 P.M. Eighteen birds were caught during each sampling time and slaughtered on the spot by bleeding at the cervical region. The carcass of the birds were opened and full crop and gizzard contents were taken and weighed. Thereafter, the crop and gizzard of the individual birds were identified visually and weighed. All samples were kept in a freezer for chemical analysis. They were brought to Animal Nutrition Laboratory, BAU, Mymensingh and then dried in an oven at $60 \circ \mathrm{C}$ and weighed after drying. The dried CGC were ground with the help of a grinding machine.

Table 1. Number of birds and plan for slaughtering

\begin{tabular}{llllllll}
\hline \multirow{2}{*}{ Areas } & \multicolumn{6}{c}{ Genotypes } \\
\cline { 2 - 6 } & \multicolumn{2}{c}{ Muscovy } & \multicolumn{2}{c}{ Pekin } & \multicolumn{2}{c}{ Desi White } & Total \\
\cline { 2 - 6 } & C & S & C & S & C & S & \\
\hline Noakhali & 3 & 3 & 3 & 3 & 3 & 3 & 18 \\
Mouza & & & & & & & \\
Ewazbalia & 3 & 3 & 3 & 3 & 3 & 3 & 18 \\
Karomullah & 3 & 3 & 3 & 3 & 3 & 3 & 18 \\
Sub Total & 9 & 9 & 9 & 9 & 9 & 9 & 54 \\
\hline
\end{tabular}

C, control; S, supplement

The samples were analyzed for proximate components, calcium ( $\mathrm{Ca}$ ) and total phosphorus (TP) contents. The proximate components (dry matter, crude protein, crude fiber, ether extract, ash, nitrogen free extract) were determined by following the method of AOAC (2004). Calcium and total phosphorus content of the samples was also determined following the method of Page et al. (1982). Each sample was replicated twice to have the proximate components.

The true metaboligable energy (TME) of CGC was determined by an indirect method using the formula of Wiseman (1987). According to Wiseman, TME $=3951+54.4 \mathrm{EE}-88.7 \mathrm{CF}-40.8$ Ash; where, $\mathrm{EE}=\%$ of ether extract, $\mathrm{CF}=\%$ of crude fiber, Ash $=\%$ of ash.

The statistical analyses of the data on different parameters were performed by the analysis of variance corresponding to a 2 (Feeding regimes) $\times 3$ (Genotypes) factorial experiment in a Randomized Block Design (Steel and Torrie, 1980) using a MSTAT-C statistical package program.

\section{Results and Discussion}

It is observed from Table 2 that there was a variation in fresh and dry weight of crop and gizzard content (CGC) among genotypes and feeding regimes. The highest weight of CGC found in Muscovy ( $85 \mathrm{~g}$ and $49 \mathrm{~g}$ ) followed by 
Rahman et al. (2014) Bang. J. Anim. Sci. 43 (3): 185- 191

Pekin (81g and 48g) and Desi white $(68 \mathrm{~g}$ and $43 \mathrm{~g}$ ) at 14 weeks of age for supplemented group. The nature of variation in non-supplemented group was similar. The values found in this experiment were higher than that of Mwalusanya et al. (2002) and Rashid et al. (2003). The overall mean weight of CGC observed in this study for different genotypes was higher than the value as reported by Biswas et al. (2005).

The major components of CGC were visually categorized according to the nature of ingredients into grains, grain by-products, animal and vegetable protein source, green forages, mineral source and others (Table 3). The physical composition of CGC of ducklings classified into grain and grain by-products constituted the major ingredients (89-91\%) during the study period for supplemented and control group irrespective of genotypes. The animal and vegetable protein were visually categorized and constituted 5-6\% of CGC. Beside these, green forages, mineral sources and some unidentified materials were also swallowed by the ducklings and become a part of crop and gizzard content. The higher occurrence of grain and grain by-products in the duck crop and gizzard might be due to the consumption of huge amount of whole paddy, rice, broken rice, rice husk and rice polish available in the scavenging areas. This finding was closely related to the works of Ali (2002), Rashid et al. (2003) and Biswas et al. (2005).

The dry matter (DM) content and the chemical composition of CGC of different genotypes of ducklings at 6,10 and 14 weeks of age are presented in Table 4 . The DM content $(\mathrm{g} / 100 \mathrm{~g}$ sample) of CGC of different genotypes of ducklings ranged between 87.00 and $89.00 \%$ for 6,10 and 14 weeks of age which well agreed with the findings of Ukil (1992), Huque (1999), Huque and Ukil (1998), Gunaratne et al. (1993) and Tadelle et al. (2002). The DM values of CGC were not affected by feed $(p>0.05)$ at 10 and 14 weeks of age but genotypes had a significant effect $(p<0.05)$ on DM content during the same period.

Table 2. Weight of crop and gizzard content (CGC) of three genotypes of ducklings at 6,10 and 14 weeks of age

\begin{tabular}{|c|c|c|c|c|c|c|c|c|c|c|}
\hline \multirow{3}{*}{ Parameters } & \multirow{3}{*}{$\begin{array}{l}\text { Age in } \\
\text { weeks }\end{array}$} & \multicolumn{6}{|c|}{ Genotypes } & \multirow{2}{*}{\multicolumn{3}{|c|}{ SED and level of significance }} \\
\hline & & \multicolumn{2}{|c|}{ Muscovy } & \multicolumn{2}{|c|}{ Pekin } & \multicolumn{2}{|c|}{ Desi White } & & & \\
\hline & & C & $\mathrm{S}$ & C & $\mathrm{S}$ & $\mathrm{C}$ & $\mathrm{S}$ & G & $\mathrm{F}$ & $\mathrm{G} \times \mathrm{F}$ \\
\hline \multirow{3}{*}{$\begin{array}{l}\text { Fresh weight of } \\
\text { CGC (g) }\end{array}$} & 6 & $68.45^{b}$ & $76.35^{a}$ & $65.15^{c}$ & $72.17^{b}$ & $52.05^{\mathrm{e}}$ & $59.92^{d}$ & $0.35^{\text {t* }}$ & $0.28^{\text {t*t }}$ & $0.49^{\mathrm{NS}}$ \\
\hline & 10 & $73.32^{b}$ & $80.58^{a}$ & $70.44^{c}$ & $74.56^{\mathrm{b}}$ & $58.19 \mathrm{e}$ & $63.87^{d}$ & $0.99^{*+}$ & $0.81^{* *}$ & $1.40^{\mathrm{NS}}$ \\
\hline & 14 & $77.01^{c}$ & $84.50^{a}$ & $72.20^{d}$ & $81.16^{b}$ & $60.18^{\dagger}$ & $67.90 \mathrm{e}$ & $0.94^{* *}$ & $0.77^{\text {*t }}$ & $1.32^{\mathrm{NS}}$ \\
\hline \multirow{3}{*}{$\begin{array}{l}\text { Dry weight of } \\
\text { CGC (g) }\end{array}$} & 6 & $43.46^{\mathrm{ab}}$ & $45.36^{a}$ & $41.64 \mathrm{bc}$ & $43.86^{a}$ & $39.54 c$ & $40.57 \mathrm{c}$ & $0.75^{\text {t* }}$ & $0.61^{+t+}$ & $1.05^{\mathrm{NS}}$ \\
\hline & 10 & $44.35 \mathrm{abc}$ & $47.24 a$ & $42.90 \mathrm{abc}$ & $45.39 \mathrm{ab}$ & $40.45 c$ & $42.38 \mathrm{bc}$ & $1.19^{*}$ & $0.98^{* *}$ & $1.69 \mathrm{NS}$ \\
\hline & 14 & $45.18^{b}$ & $48.89^{a}$ & $43.85^{b}$ & $47.72^{\mathrm{a}}$ & $40.95^{c}$ & $42.92^{b c}$ & $0.85^{\text {t* }}$ & $0.69^{* *}$ & $1.20^{\mathrm{NS}}$ \\
\hline
\end{tabular}

C, control; S, supplement; G, genotype; F, feed; Figures with different superscripts in a row differ significantly; ${ }^{*}, p<0.05,{ }^{*}, p<0.01, N S$, nonsignificant.

Table 3. Crop and gizzard content of ducklings of different genotypes ( $\mathrm{g} / 100 \mathrm{~g}$ sample)

\begin{tabular}{|c|c|c|c|c|c|c|c|c|c|}
\hline \multirow{3}{*}{ Parameters } & \multicolumn{6}{|c|}{ Genotypes } & \multirow{2}{*}{\multicolumn{3}{|c|}{ SED and level of significance }} \\
\hline & \multicolumn{2}{|c|}{ Muscovy } & \multicolumn{2}{|c|}{ Pekin } & \multicolumn{2}{|c|}{ Desi White } & & & \\
\hline & $\mathrm{C}$ & $\mathrm{S}$ & C & S & C & $\mathrm{S}$ & G & $\mathrm{F}$ & $\mathrm{G} \times \mathrm{F}$ \\
\hline Grain & $53.80^{a}$ & $45.30^{a}$ & $52.43^{a b}$ & $54.00^{a}$ & $51.20^{b}$ & $53.20^{a b}$ & $0.83^{\mathrm{NS}}$ & $0.68^{\mathrm{NS}}$ & $1.17^{\mathrm{NS}}$ \\
\hline Grain by-product & $35.70^{b c}$ & $34.00^{c}$ & $37.97^{b}$ & $35.35^{b}$ & $40.55^{a}$ & $37.75^{b}$ & $0.91^{\text {** }}$ & $0.74^{* *}$ & $1.28 \mathrm{NS}$ \\
\hline Animal protein & $2.75^{a}$ & $2.95^{a}$ & $2.50^{b}$ & $2.85^{a}$ & $2.25^{c}$ & $2.35 \mathrm{bc}$ & $0.24^{* *}$ & $0.19^{* *}$ & $0.34 \mathrm{NS}$ \\
\hline Vegetable protein & $3.30^{\mathrm{ab}}$ & $3.50^{a}$ & $3.00 \mathrm{~cd}$ & $3.20^{b c}$ & $2.60^{\mathrm{e}}$ & $2.90^{d}$ & $0.01^{\text {** }}$ & $0.09^{\star *}$ & $0.15^{\mathrm{NS}}$ \\
\hline Green forage & $1.25^{b}$ & $1.50^{a}$ & $1.10^{c}$ & $1.30^{\mathrm{b}}$ & $0.75^{d}$ & $0.85^{d}$ & $0.04^{* *}$ & $0.03^{* *}$ & $0.06^{\mathrm{NS}}$ \\
\hline Mineral source & $2.20^{b}$ & $2.50^{a}$ & $2.05^{c}$ & $2.25^{b}$ & $1.75^{d}$ & $2.00^{c}$ & $0.05^{\star \star}$ & $0.04^{* *}$ & $0.08 \mathrm{NS}$ \\
\hline Others (Unidentified) & $1.00 \mathrm{bc}$ & $1.25^{a}$ & $0.95 c$ & $1.05^{b}$ & $0.85^{d}$ & $0.95 c$ & $0.03^{* *}$ & $0.02^{* *}$ & $0.04 \mathrm{NS}$ \\
\hline
\end{tabular}

C, control; S, supplement; $G$, genotype; $F$, feed; Figures with different superscripts in a row differ significantly, ${ }^{*}(P<0.05)$, ** $(P<0.01), N S$, nonsignificant 


\section{Crop and gizzard contents of ducklings}

Table 4. Chemical composition of crop and gizzard content of different genotypes of ducklings at 6,10 and 14 weeks of age ( $\mathrm{g} / 100 \mathrm{~g} \mathrm{DM})$

\begin{tabular}{|c|c|c|c|c|c|c|c|c|c|c|}
\hline \multirow{3}{*}{ Parameters } & \multirow{3}{*}{$\begin{array}{c}\text { Age } \\
\text { (week) }\end{array}$} & \multicolumn{6}{|c|}{ Genotypes } & \multirow{2}{*}{\multicolumn{3}{|c|}{ SED and level of significance }} \\
\hline & & \multicolumn{2}{|c|}{ Muscovy } & \multicolumn{2}{|c|}{ Pekin } & \multicolumn{2}{|c|}{ Desi White } & & & \\
\hline & & $C$ & $\mathrm{~S}$ & $C$ & $\mathrm{~S}$ & $C$ & $\mathrm{~S}$ & G & $F$ & $\mathrm{G} \times \mathrm{F}$ \\
\hline \multirow{3}{*}{$\begin{array}{c}\text { Dry matter } \\
\text { (g/100g sample) }\end{array}$} & 6 & $87.20 \mathrm{abc}$ & $87.55^{a}$ & $87.00^{\mathrm{bc}}$ & $87.35^{\mathrm{ab}}$ & $86.90^{c}$ & $87.20 \mathrm{abc}$ & $0.13^{\mathrm{NS}}$ & $0.11^{*}$ & $0.19 \mathrm{NS}$ \\
\hline & 10 & $88.25^{a}$ & $88.38^{a}$ & $88.00^{a}$ & $88.70^{a}$ & $87.95^{a}$ & $88.50^{a}$ & $1.20^{*}$ & $0.98 \mathrm{NS}$ & $1.70^{\text {t* }}$ \\
\hline & 14 & $88.60 a$ & $88.90 a$ & $88.40 \mathrm{a}$ & $88.75^{a}$ & $88.25^{a}$ & $88.65^{a}$ & $0.96^{*}$ & $0.78 \mathrm{NS}$ & $1.30^{\text {*t }}$ \\
\hline \multirow{3}{*}{$\begin{array}{l}\text { Crude protein } \\
\text { (CP) }\end{array}$} & 6 & $12.00^{\mathrm{ab}}$ & $12.50^{\mathrm{a}}$ & $11.85^{b c}$ & $12.23 \mathrm{ab}$ & $10.15^{d}$ & $11.38^{c}$ & $0.21^{\text {*t }}$ & $0.17^{\text {th }}$ & $0.30^{\mathrm{NS}}$ \\
\hline & 10 & $10.69 \mathrm{ab}$ & $10.84 a$ & $10.53^{b}$ & $10.77^{a}$ & $9.09 c$ & $9.29 c$ & $0.08^{* *}$ & $0.06^{*+*}$ & $0.11^{\mathrm{NS}}$ \\
\hline & 14 & $9.29 b$ & $9.73^{a}$ & $8.03^{d}$ & $8.65^{c}$ & $7.71^{\mathrm{e}}$ & $7.95^{\mathrm{de}}$ & $0.09^{* *}$ & $0.07^{\text {t* }}$ & $0.12^{\mathrm{NS}}$ \\
\hline \multirow{3}{*}{ Crude fibre (CF) } & 6 & $12.28^{b}$ & $12.60^{a}$ & $12.81^{a}$ & $12.75^{\mathrm{a}}$ & $12.50^{\mathrm{ab}}$ & $11.25^{c}$ & $0.01^{\text {*t }}$ & $0.09^{\text {th }}$ & $0.17^{\text {th }}$ \\
\hline & 10 & $14.04^{c}$ & $13.30^{d}$ & $13.92^{\mathrm{cd}}$ & $14.74^{\mathrm{ab}}$ & $14.25^{b c}$ & $15.29 \mathrm{a}$ & $0.24^{* *}$ & $0.19^{\mathrm{NS}}$ & $0.34^{*+*}$ \\
\hline & 14 & $14.65^{b c}$ & $13.56^{d}$ & $14.20^{c}$ & $13.43^{d}$ & $15.04^{a b}$ & $15.27^{a}$ & $0.21^{* *}$ & $0.17^{\star}$ & $0.29^{*}$ \\
\hline \multirow{3}{*}{$\begin{array}{l}\text { Ether extract } \\
\quad(\mathrm{EE})\end{array}$} & 6 & $1.96^{\mathrm{d}}$ & $3.30^{\mathrm{b}}$ & $1.88^{\mathrm{d}}$ & $3.73^{a}$ & $1.58^{\mathrm{e}}$ & $2.52^{c}$ & $0.04^{\text {th }}$ & $0.03^{\text {th }}$ & $0.05^{\text {th }}$ \\
\hline & 10 & $2.56^{\mathrm{d}}$ & $2.68^{c}$ & $2.45^{\mathrm{e}}$ & $4.13^{a}$ & $2.10^{f}$ & $3.80^{\mathrm{b}}$ & $0.02^{* *}$ & $0.01^{* *}$ & $0.03^{\text {t* }}$ \\
\hline & 14 & $3.36^{b}$ & $3.42^{b}$ & $2.03^{d}$ & $2.53^{c}$ & $3.51^{b}$ & $4.40^{\mathrm{a}}$ & $0.10^{* *}$ & $0.03^{\text {t*x }}$ & $0.14^{*+*}$ \\
\hline \multirow{3}{*}{ Ash } & 6 & $16.40^{c}$ & $15.44 \mathrm{e}$ & $15.16 \mathrm{e}$ & $16.05^{d}$ & $17.72^{\mathrm{b}}$ & $19.53^{a}$ & $0.10^{\text {t* }}$ & $0.08^{*+2}$ & $0.15^{\text {th }}$ \\
\hline & 10 & $16.01^{a}$ & $14.70^{c}$ & $16.21^{a}$ & $14.25^{d}$ & $15.65^{b}$ & $14.40^{d}$ & $0.12^{*}$ & $0.10^{\text {t* }}$ & $0.17^{\text {t* }}$ \\
\hline & 14 & $15.35^{b}$ & $14.25^{d}$ & $15.00^{c}$ & $13.75^{e}$ & $16.09 a$ & $13.23^{f}$ & $0.12^{*}$ & $0.09^{* *}$ & $0.17^{\text {*t }}$ \\
\hline \multirow{3}{*}{$\begin{array}{l}\text { Nitrogen-free- } \\
\text { extract (NFE) }\end{array}$} & 6 & $57.39^{a b}$ & $56.16^{\mathrm{ab}}$ & $58.30^{a}$ & $55.24^{b}$ & $58.05^{a}$ & $55.32^{b}$ & $0.90^{\mathrm{NS}}$ & $0.73^{*}$ & $1.20^{\mathrm{NS}}$ \\
\hline & 10 & $56.70^{b}$ & $58.48^{a}$ & $56.48^{b}$ & $56.11^{b}$ & $58.91^{a}$ & $57.22^{b}$ & $0.42^{*}$ & $0.34^{\mathrm{NS}}$ & $0.59^{*+k}$ \\
\hline & 14 & $57.44^{c}$ & $59.04 b c$ & $60.74 a b$ & $61.14 a$ & $57.65^{c}$ & $59.15^{b c}$ & $0.67^{\text {t* }}$ & $0.54^{*}$ & $0.97 \mathrm{NS}$ \\
\hline \multirow{3}{*}{ Calcium (Ca) } & 6 & $1.20^{b}$ & $0.76^{d}$ & $1.11^{c}$ & $0.75^{d}$ & $2.68^{a}$ & $2.66^{\mathrm{a}}$ & $0.03^{\text {*t* }}$ & $0.02^{\text {t*t }}$ & $0.04^{\text {t+t }}$ \\
\hline & 10 & $2.82^{\mathrm{a}}$ & $1.43^{c}$ & $2.46^{b}$ & $0.59 \mathrm{~d}$ & $1.30 c$ & $1.34 c$ & $0.10^{* *}$ & $0.08^{* *}$ & $0.14^{* *}$ \\
\hline & 14 & $1.74^{a}$ & $1.65^{b}$ & $0.45^{f}$ & $0.60^{\mathrm{e}}$ & $1.35^{c}$ & $0.68^{d}$ & $0.03^{\text {** }}$ & $0.02^{* *}$ & $0.03^{\text {t* }}$ \\
\hline Total & 6 & $0.28^{d}$ & $0.58^{a}$ & $0.26^{\text {de }}$ & $0.37 c$ & $0.22^{e}$ & $0.46^{b}$ & $0.02^{*+*}$ & $0.01^{*+}$ & $0.03^{\text {th }}$ \\
\hline \multirow{2}{*}{$\begin{array}{c}\text { phosphorus } \\
\text { (TP) }\end{array}$} & 10 & $0.76^{a}$ & $0.39 c$ & $0.79^{a}$ & $0.21^{\mathrm{d}}$ & $0.70^{b}$ & $0.35^{c}$ & $0.02^{* *}$ & $0.01^{\star *}$ & $0.02^{* *}$ \\
\hline & 14 & $0.37 c$ & $0.40^{b}$ & $0.21 \mathrm{e}$ & $0.19^{f}$ & $0.46^{a}$ & $0.27 \mathrm{~d}$ & $0.005^{* *}$ & $0.004^{* *}$ & $0.003^{* *}$ \\
\hline \multirow{3}{*}{$\begin{array}{c}\text { True } \\
\text { metabolizable } \\
\text { energy (TME) } \\
\text { (kcal/kg DM) }\end{array}$} & 6 & 2301.92 & 2382.95 & 2298.49 & 2368.14 & 2205.22 & 229338 & $65.10^{\mathrm{NS}}$ & $53.15^{\mathrm{NS}}$ & $92.06^{\mathrm{NS}}$ \\
\hline & 10 & $2191.70^{b c}$ & $2317.32^{a}$ & $2188.21^{b c}$ & $2268.83 a$ & $2162.74 c$ & $2213.98^{b}$ & $15.25^{* *}$ & $12.45^{* *}$ & $21.57 \mathrm{NS}$ \\
\hline & 14 & $2216.03^{c}$ & $2353.29 a$ & $2189.89 \mathrm{~cd}$ & $2336.39 \mathrm{ab}$ & $2115.42^{d}$ & $2296.14^{b}$ & $19.92^{* *}$ & $16.27^{* *}$ & $28.18^{\mathrm{NS}}$ \\
\hline
\end{tabular}

C, control; S, supplement; G, genotype; F, feed; Figures with different superscripts in a row differ significantly; ${ }^{*}, p<0.05 ;{ }^{*}, p<0.01 ;$ NS, nonsignificant

Data shown in Table 4 revealed that CP content was higher at 6 weeks of age than at 10 and 14 weeks of age. This finding is closely associated with the works of Mwalusanya et al. (2002) who found significantly higher $\mathrm{CP}$ in crop contents of younger birds than that found in adult. The mean value of CP (11.69\%) at 6 weeks of age in CGC of present study was markedly higher than the values of $8.18 \%$ and $9.62 \%$ reported by Ukil (1992) and Ali (2002), respectively. Genotypes and feed had a significant effect $(p<0.01)$ on CP content in CGC at 6,10 and 14 weeks of age but interaction between genotypes and feed showed no significant effect $(p>0.05)$ on CP of CGC. The variation in $\mathrm{CP}$ contents in CGC among genotypes may be an indication of variability of protein source. The values of CP in CGC was lower than the value of $15 \%$ as reported by Tadelle et al. (2002). The higher CP value of CGC might be due to the greater consumption of protein rich feed ingredients like insects, worms, small fishes, oyster, crabs, snails and duckweeds available in the study areas. This findings were in agreement with the works of Huque and Ukil (1998), Rahman and Howlider (2006), Mwalusanya et al. (2002), Biswas et al. (2005) and Gunaratne et al. (1993). 
The CF content in CGC of different genotypes of ducklings varied from 11 to $15 \%$ for 6,10 and 14 weeks of age which was close to the findings of Huque and Ukil (1998), Huque (1999) and Tadelle et al. (2002). The mean value of CF $(13 \%)$ in CGC of present experiment was markedly higher than the values of $8.46 \%$ and 9.62\% reported by Rahman and Howlider (2006) and Ali (2002), respectively and slightly lower than the values as reported by Biswas et al. (2005). Significant variation $(p<0.01)$ in CF content in CGC was found among the genotypes with higher values for older birds. But Mwalusanya et al. (2002) found slightly higher CF in crop contents of growing birds than in adults. Higher CF values in CGC for older birds may be related to their higher scavenging ability of forages. Feed showed no significant $(p>0.05)$ effect on CF content in CGC at 10 weeks of age but interaction between genotypes and feed had a significant effect on CF content in CGC during the experimental period.

The mean value of EE ( $3 \%$ ) in CGC of the present study was markedly higher than the values of $1.5 \%, 1.7 \%$ and $1.61 \%$ as reported by Huque and Ukil (1998), Huque (1999) and Huque et al. (1994), respectively. Results recorded in Table 4 showed that EE values of CGC was in close agreement with the findings of Biswas et al. (2005) and Tadelle et al. (2002) but remarkably lower than the value as reported by Mwalusanya et al. (2002). Genotypes, feed and interaction between genotype and feed showed significant variation $(p<0.01)$ in EE content of CGC during the experimental period.

Ash content of CGC was lower at older age than that found in case of younger birds (Table 4) being in agreement with the findings of Mwalusanya et al. (2002). The mean value of ash (16.69\%) in CGC was much higher than the values of $10.99 \%$ and $10.69 \%$ reported by Huque (1999) and Rahman and Howlider (2006), respectively. The ash availability in CGC in the present study was almost similar to the findings of Tadelle et al. (2002) and Biswas et al. (2005). Feed showed significant $(P<0.01)$ effect on ash content in CGC at 6,10 and 14 weeks of age and interaction between genotypes and feed also showed significant variation $(p<0.01)$ for the same period.
The NFE content in CGC ranged between 55\% and $62 \%$ at 6,10 and 14 weeks of age which was very close to the findings of Haque and Ukil (1998), Huque (1999) and Huque et al. (1994). The mean value of NFE (58\%) in CGC of the present study was slightly higher than the values of $53 \%$ and $54 \%$ as reported by Ukil (1992) and Biswas et al. (2005), respectively. Interaction between genotypes and feed had no significant effect $(p>0.05)$ on NFE in CGC at 6 and 14 weeks of age but it had a significant variation $(P<0.01)$ at 10 weeks of age.

Results shown in Table 4 showed indicate that $\mathrm{Ca}$ values of CGC varied from 0.59 to $2.82 \%$ during 6,10 and 14 weeks of age. Ca content of CGC was slightly lower than the values as reported by Huque (1999), Ukil (1992) and Huque et al. (1994) but the results were slightly higher than the reports of Rahman and Howlider (2006), Tadelle et al. (2002) and Mwalusanya et al. (2002). The mean value of Ca content $(1.42 \%)$ in CGC in the present study was close to the findings of Biswas et al. (2005). Genotypes, feed and interaction between genotypes and feed showed significant effect $(p<0.01)$ on $\mathrm{Ca}$ content in CGC at 6, 10 and 14 weeks of age.

The mean value of TP $(0.33 \%)$ in CGC of present experiment was more or less similar to the earlier findings $(0.30 \%$ and $0.34 \%)$ reported by Huque and Ukil (1990) and Biswas et al. (2005), respectively. The mean value of TP content was in well agreement with the reports of Rahman and Howlider (2006) but remarkably lower than the values reported by Tadelle et al. (2002) and Huque (1999). Genotypes, feed and interaction between genotypes and feed showed significant effect $(p<0.01)$ on TP content in CGC at 6,10 and 14 weeks of age.

The mean value of TME (2266 kcal/ kg DM) in CGC was markedly lower than the values 2678 and $2864 \mathrm{kcal} / \mathrm{kg}$ DM reported by Rahman and Howlider (2006) and Tadelle et al. (2002). The results of the present study was more or less similar to the findings of Biswas et al. (2005). Genotypes, feed and interaction between genotypes and feed showed no significant effect ( $p>0.05$ ) on TME in CGC at 6 weeks of age but genotypes and feed had a significant variation $(p<0.01)$ on TME in CGC at 10 and 14 weeks of age. 


\section{Crop and gizzard contents of ducklings}

\section{Conclusion}

The major nutrients ( $\mathrm{CP}, \mathrm{Ca}, \mathrm{TP}$ and TME) in crop and gizzard contents appeared to be very low to support satisfactory production potential. It can also be concluded that the nutritional status of scavenging ducklings under rural management condition was below the requirements. The information obtained in the present study would be a basis for formulating nutrient supplementation policies for scavenging ducklings using the locally available feed resources. However, genotypes, feed, climate, season and age of birds should be given utmost importance to deal with nutritional status of scavenging ducklings in coastal areas of Bangladesh.

\section{Acknowledgement}

The author highly acknowledges the research funding of Smallholder Livestock Development Project-2 (SLDP-2) sponsored by DANIDA-DLS.

\section{References}

Ali MS (2002). Study on the effect of feed supplementation to laying hen under the rural condition of Bangladesh. M. Sc. Thesis. The Royal Veterinary and Agricultural University, Denmark.

AOAC (2004). Official Methods of Analysis. Association of Official Analytical Chemists. Washington DC.

Biswas MSA, Chowdhury SD, Mustafa MG, Bell J (2005). Availability and nutrient status of scavengable feed resources in crop and gizzard contents of scavenging ducklings in Bangladesh. Proceedings of the $4^{\text {th }}$ International Poultry Show and Seminar, World's Poultry Science Association, Bangladesh Branch, 167-172.

Gunaratne SP, Chandrasiri DN, Mangalika Hemalatha WAP, Roberts JA (1993). Feed resources base for scavenging chickens in Sri Lanka. Tropical Animal Health and Production, 25: 249-257.

Huque QME, Ukil MA, Haque ME, Hossain MJ (1994). Nutrient content in scavenging feed of laying ducks in Bangladesh. Bangladesh Journal of Scientific and I ndustrial Research, 29: $70-76$.
Huque QME (1999). Nutritional status of family poultry in Bangladesh. Livestock Research for Rural development, 11: 3-8.

Huque QME, Ukil MA (1990). Feeding pattern of birds (chicken and ducklings) under scavenging condition and formulation of supplementary ration using the local ingredients. Second Annual Progress Report. Poultry Production Research Division, Bangladesh Livestock Research Institute, Savar, Dhaka.

Huque QME, Ukil MA (1998). Energy content of feeds consumed by scavenging chicken and duck in Bangladesh. Bangladesh Journal of Livestock Research, 5: 103-113.

Mwalusanya NA, Katule AM, Mutayoba SK, Minga UM, Mtambo MMA, Olsen JE (2002). Nutrient status of crop contents of rural scavenging local chickens in Tanzania. British Poultry Science, 46: 64-69.

Page AL, Miller RH, Keeny RR (1982). Methods of soil analysis. Part 2. American Society for Agronomy, USA.

Rahman MS, Howlider MAR (2006). Nutrients availability to scavenging chickens in Bangladesh. International J ournal of Poultry Science, 5: 275-278.

Rashid MM, Lauridsen C, Roy BC, Islam MN (2003). Nutrient concentrations of crop contents of indigenous scavenging chickens under rural conditions of Bangladesh. Department of Animal Nutrition and Physiology, Danish Institute of Agricultural Sciences, Denmark, P. 37-48.

Roberts JA, Gunaratne SP (1992). The scavenging feed resource base for village chickens in a developing country. In: Proceedings of the $19^{\text {th }}$ World Poultry Congress, Amsterdam, The Netherlands, P. 822-825.

Singh PK, Khatta VK, Thakur RS, Dey S, Sangwan ML (2003). Effects of phytase supplementation on the performance of broiler chickens fed maize and wheat based diets with different levels of non-phytate phosphorus. Asian-Australasian Journal of Animal Sciences, 16: 1642-1649.

Steel RGD, Torrie JH (1980). Principles and procedures of statistics, $2^{\text {nd }}$ Edition, McGraw-Hill Book Co. Inc. USA.

Tadelle D, Ogle B (2000). Nutritional status of 
Rahman et al. (2014) Bang. J. Anim. Sci. 43 (3): 185- 191

village poultry in the central highlands of Ethiopians assessed by analyses of crop contents. Ethiopian Journal of Agriculture Science, 17: 47-57.

Tadelle D, Nigusie D, Alemu Y, Peters KJ (2002). The feed resource base and its potential for increased poultry production in Ethiopia. World's Poultry Science J ournal, 58: 77-87.

Ukil MA (1992). Availability of nutrients to scavenging chickens and ducklings in Bangladesh. M. Sc. Thesis. Department of Poultry Science, Bangladesh Agricultural University, Mymensingh, Bangladesh.

Wiseman J (1987). Feeding of Non-ruminant Livestock. P. 9-13. 